$$
\text { At the Interface }
$$

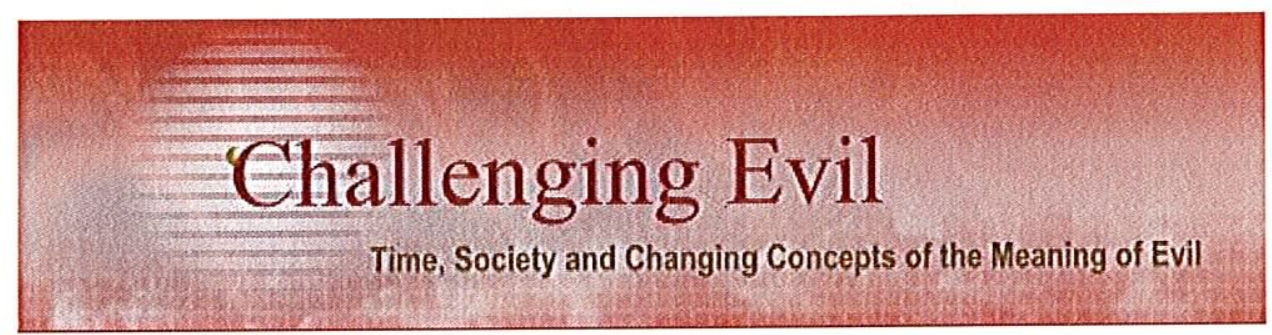

Edited by

Johannes Schlegel \& Brita Hansen

Inter-Disciplinary Press 


\title{
At the Interface
}

\author{
Series Editors \\ Dr Robert Fisher \\ Dr Daniel Riha
}

\begin{abstract}
Advisory Board
Dr Alejandro Cervantes-Carson

Professor Margaret Chatterjee

Dr Wayne Cristaudo

Mira Crouch

Dr Phil Fitzsimmons

Professor Asa Kasher

Owen Kelly

Dr Peter Mario Kreuter Martin McGoldrick

Revd Stephen Morris

Professor John Parry Paul Reynolds

Professor Peter Twohig Professor S Ram Vemuri Revd Dr Kenneth Wilson, O.B.E
\end{abstract}

An At the Interface research and publications project.

http://www.inter-disciplinary.net/at-the-interfacel

The Evil Hub

'Perspectives on Evil and Human Wickedness'

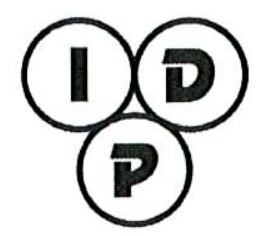




\section{Challenging Evil: \\ Time, Society and Changing Concepts of the \\ Meaning of Evil}

Edited by

Johannes Schlegel \& Brita Hansen

Inter-Disciplinary Press

Oxford, United Kingdom 


\section{(C) Inter-Disciplinary Press 2010 \\ http://www.inter-disciplinary.net/publishing/id-press/}

The Inter-Disciplinary Press is part of Inter-Disciplinary.Net - a global network for research and publishing. The Inter-Disciplinary Press aims to promote and encourage the kind of work which is collaborative, innovative, imaginative, and which provides an exemplar for inter-disciplinary and multidisciplinary publishing.

All rights reserved. No part of this publication may be reproduced, stored in a retrieval system, or transmitted in any form or by any means without the prior permission of Inter-Disciplinary Press.

Inter-Disciplinary Press, Priory House, 149B Wroslyn Road, Freeland, Oxfordshire. OX29 8HR, United Kingdom.

$+44(0) 1993882087$

British Library Cataloguing in Publication Data. A catalogue record for this book is available from the British Library.

ISBN: 978-1-84888-026-9

First published in the United Kingdom in eBook format in 2010. First Edition. 


\section{Table of Contents}

Introduction

Johannes Schlegel and Brita Hansen

PART 1: $\quad$ Contemporary Political and Legal Challenges of Evil

Cruelties Well Used? Machiavelli and the Contemporary Debate over Torture

William Andrew Myers

Evil, Toxic, and Pathological Categories of Leadership: Implications for Political Power William W. Bostock

Spreading the Word: Evangelism and the Posturing of Evil

George Catsi

Shifting Political Discourses of Israeli Officials toward the Palestinian Authority within the Boundaries of Economy Politics

Ali Kemal Yenidunya

Criminal Legal Confrontation with Evil in Cases of Sexually Abused Children

Dalida Rittossa

PART 2: $\quad$ Challenging Evil and Philosophy

Aristotle's Concious Evil Typology

Manuel Oriol-Salgado

Evil, Freedom, and the Heaven Dilemma

Simon Cushing

PART 3: $\quad$ Literary Imaginations of Evil

The Voice of the Devil: Milton, Blake and the Mediality of Evil

Johannes Schlegel 
The Concept of Evil in H.G. Wells' Novel

The Island of Dr. Moreau

Cem Orhan

An Archetypal Evil: A Passage to India

Cumhur Yilmaz Madran

From Oral Folk Tale Tradition to Fairy Tales and Their Representations in the Postmodern Novel: Once Upon a Time where Evil Resides

Seyda Inceoglu

Embracing the Unknowable: Suffering and

Death in J.M.Coetzee's Age of Iron

Marek Pawlicki

Voldemort \& Co.: Immortality and Immorality in the Harry Potter Series

Katarzyna Malecka

Confronting Evil in Harry Potter

Dana Lori Chalmers

PART 4: $\quad$ Multimedia Forms of Evil

Darkfic Slash: Are Evil Phantasies Dangerous?

Brita Hansen

It's Hard to be Evil: Good, Evil, and Moral

Clarity in Video Games

Cynthis Yans Mayer \& Robert R. Mayer

Ataman Struk Has His Photograph Taken:

Testimony and Portraiture in the Russian Civil

War Period

Anne Brennan

PART 5: $\quad$ Representations of Evil in Art/History

Defining and Confronting Evil in the Sources of the Crusades 


\title{
Ataman Struk Has His Photograph Taken: Testimony and Portraiture in the Russian Civil War Period
}

\author{
Anne Brennan
}

\begin{abstract}
This paper examines a collection of photographic portraits of Ataman Struk, a notorious pogrom perpetrator of the Russian Civil War period, and his henchmen. The portraits formed part of an archive of images collected by the Jewish historian Elias Tcherikower documenting the impact of the pogroms perpetrated during the Civil War period. This paper explores the tension between the portraits' essentially private status, and the historical uses to which they have been put in the archive. Through considering the photograph as a locus of the competing desires of subject, photographer and viewer, the paper argues that the images have gained a set of retrospective meanings as unconscious projections of the anarchic conditions of the Civil War period.
\end{abstract}

Key Words: Ataman Struk, Elias Tcherikower, photographic portrait, pogrom, Russian Civil War, studio photography.

Imagine this: you are sitting in an archive in a country a long way away from home. You are looking for photographs of the city in the Ukraine where your mother was born. This city, so far as it is remembered at all, is remembered for one thing. In 1919, in the dying days of the Russian Civil War, it was the site of a terrible massacre of Jews.

You have been looking for photographs of the town, but haven't found any. There are images of the victims of the pogrom, but nothing to tell you more about the city itself: its streets and houses, its considerable preRevolutionary Jewish community immersed in their lives before the twentieth century happened to them.

There is one more thing to look at. It is a roll of microfilm buried in the papers of a Jewish historian of the pogroms that swept Ukraine in 1919. The roll is labelled 'Photographs of Pogrom Victims'. If the rest of the archive has failed to render up images of the city, then perhaps here a picture might inadvertently show you something else: a streetscape, maybe, or a house.

You loop the film into the microfilm reader. The tape advances slowly. On the screen you see at first the scratches and marks on the bare tape, like some kind of visual white noise. Then some text appears: 'Tcherikower Archive Roll 52 File 622 54469-54501.' Some more white noise, and then a copy of an old museum label. This is followed by an image 
of an envelope inscribed in Yiddish and Russian. Then, slowly, moving from right to left, a photograph. It is not very big, no more than about $9 \mathrm{~cm} \times 6 \mathrm{~cm}$.

This image, and the ones that follow it, are a catalogue of the worst things it is possible to imagine human beings visiting upon each other. Noone seems to have been spared: men, women, children and the elderly figure in pictures that record mass graves, despoiled and desecrated synagogues and records of appallingly injured survivors. There is a primitively cinematic quality to the way in which the tape unspools its record of violence that suggests a narrative of some sort, and you are transfixed, waiting to see what happens next.

What happens next, or more precisely, half way along the roll of microfilm, is this: very slowly, a photograph of a man comes into view. He is dressed in a large fur hat, a white collarless shirt and knee-length riding boots. A holster is strapped around his waist, a sabre belt across his chest. The context of the image is obviously a photographic studio, albeit an impoverished one, because the background to the photograph is a swag of ragged curtain, nailed to a batten at the top of a screen which is clearly visible in the photograph.

But it is the pose of the man that galvanises you: he is seated astride a child's hobbyhorse, presumably a prop of the photographer's studio. His big man's body seems to dominate the little horse, his large booted feet at odds with its dainty hooves. His left hand, which grasps the hilt of his sabre, appears to be resting on the little horse's head. In his right hand, he wields a revolver, aimed at a point somewhere out of the right hand frame of the picture. His face is turned somewhat stiffly towards the camera, as though directed to do so by someone else, and he stares straight out of the frame at you. The annotation on the back of this photograph, in Yiddish and Russian, reads 'Chernobyl (February - April 1919) (member) of the Struk gang.'

Not much is known about Struk, except that he was a warlord and pogrom perpetrator active in the Chernobyl region. Like many warlords of the period, he was a political opportunist. By 1919, all of the armies participating in the Civil War were desperate for troops. Men like Struk sold their services to whichever army offered him money. During the course of 1919 , Struk reputedly switched his allegiance to three different armies four times. ${ }^{1}$ In reality, he did not serve the interests of those to whom he sold his services, preferring instead to remain within his own sphere of influence, where he spent his time harassing local Jewish communities. It is said that his favourite way to dispatch Jews was to throw them into the Dnieper River, where they would drown, their bodies floating downriver towards Kiev. ${ }^{2}$ It has been estimated that he was responsible for at least 1000 Jewish deaths between 1919-1920. 
The photograph of the man on the hobbyhorse is one of about twelve images, clearly taken in a single session in the same derelict studio. There are approximately eighteen subjects, mostly male: at least nine of them are adolescents, and four of these appear to be no more than about thirteen or fourteen. Two older men are depicted with their families.

The subjects are dressed in a miscellany of remnants of Cossack, Tsarist army uniforms and street clothes, mostly ill-fitting and worn. The men pose individually and in groups, stiffly formal: hieratic, even. They address the camera four-square, their hands upon their knees, their unsmiling faces staring directly into the camera's lens. In some of the images they rest their hands on each other's shoulders.

In several of the photographs, the men display their weapons. In two pictures, young men grasp revolvers at chest height, the gun presented in profile to the camera, the barrel pointing to the subject's left, as though it is directed at the comrade at their side. In both cases, the men look straight ahead at the camera, which gives the uncanny impression that this gesture is occurring independent of their own volition. Others either wear or display their sabres, and a number of others carry whips and a small club.

The seduction of the photograph, Barthes tells us, is its status as a trace of a moment in the past. The light that reflects from the subject of a photograph burns into the photosensitive surface of a plate or film: 'From a real body, which was there, proceed radiations which ultimately touch me', he observes. ${ }^{4}$

The photograph's indexical relationship with the real allows it to participate simultaneously in two different kinds of discourses about memory. If we accept that the photograph is an unproblematic record of what it represents, it can become an authoritative documentary voice. Clearly, this belief in photographic truth lay at the heart of Tcherikower's investment in his archive as a witnessing document. At the same time, the status of the photograph as a trace of an event or a person gives it an almost magical potency. The photograph slices a moment out of time, freezing it for posterity.

Roland Barthes and Walter Benjamin argue that the photograph is in a sense timeless, since it survives the passage of time, allowing the subject to "be present in another form, in another time and place. ${ }^{5}$ Thus the photograph, and the photographic portrait in particular, promises a kind of immortality to its subjects.

But what happens when a photograph survives the conditions and circumstances of its making? Over time, the images of Struk and his men have become detached from their subjects: why and how they were made and even the men's identity are now lost to us. Furthermore, whatever their original meanings might have been, they have been destabilised by their inclusion in Tcherikower's archive. From a group of images clearly made for 
a set of private purposes, these photographs have been put at the service of history, forced into the role of documentary tool.

Every photograph is the locus of a set of desires and intentions negotiated between the subject, the photographer and the viewer. The idea of a photograph as the instrument of a single truth, then, becomes a slippery commodity. The overt performativity of the photographs of Struk and his men strains the conditions of documentary 'truth'. The pictures gesture towards the specific conditions under which they were made, but at the same time, they remain curiously mute because those conditions are no longer available to us, both occluding and opening up possibilities for interpretation.

What we do know about these photographs is contained in two sets of archival information: the original notes on the backs of the photographs themselves, presumably made by Tcherikower himself or an assistant, and the notes to the images in the YIVO online archive, made much later. The original notes are reticent in the extreme. Each image is labelled almost identically: 'Chernobyl (February - April 1919) member [or members] of the Struk gang'. Only one subject is named: Struk himself.

The online archive offers more information, usually descriptive. However, in some cases, it strays into interpretation. In one of the two group photographs that include young men holding up their revolvers, for example, the online description reads: 'Studio portrait of two teenage boys, members of Struk's rebel band which carried out pogroms: one boy (standing) points a pistol at his cohort (seated), who wears a bandolier of bullets on his coat and holds a sabre.' My first attempts to interpret this picture were shaped by this description. The possibility that they were pointing their guns at each other reinforced for me what I already thought I knew about them: that they were a group of violent thugs.

However, recently I was able to obtain high-resolution digital images of the photographs. This allowed me to see them in much greater detail. Amongst other things, when I looked at the images of the men who appeared to be pointing their pistols at their comrades, I could see that in neither case is the man with the gun standing directly next to their companion, making it more likely that their pistols are directed at a point either behind or in front of the right shoulder of their cohort. In both cases, the men grasp the butts of their weapons in their fists: they do not extend their finger to the trigger, as they might do if they were pretending to aim it at their fellows.

Two military historians from the Australian War Memorial have suggested that the behaviour of the men is about display. They told me that displaying weapons was quite common to portraits of soldiers during World War 1, usually in the context of group portraits of men in the same company or battalion. These kinds of images were made as expressions of group solidarity for private consumption, performing the role of a kind of souvenir 
or trophy. They might, for example be made before a company of soldiers shipped out for war. ${ }^{6}$

In these photographs, they pointed out, the photographer played an important role in setting up the photographic session. The poses of the men, therefore, were not entirely determined by them, but were a kind of collaboration between photographer and subject. The photographer's role was to weld a group of private individuals into an image of a company, a brotherhood. The transition from individual to group would be expressed in the coherence of its military trappings: the single identifying uniform, the same kinds of weapons, ritualistic poses.

However, in the case of these photographs, no coherent codes bond the men apart from their shared presence in the studio, the repeated gesture of the hand upon the shoulder, and perhaps the reference to the image of the Cossack, which, was linked in the popular Ukrainian imagination of the period with a form of proto-nationalist rebel. This lack of coherence allows us to see other things: the extreme youth of some of the subjects, their impoverished circumstances, the paucity of their weapons, all of which lend the images a kind of pathos.

Joshua Karlip argues that Tcherikower constantly struggled with the meaninglessness of the pogroms of this period, and that he "desperately sought to redeem contemporary Jewish suffering by linking it to the martyrdom of Jewish people throughout history. ${ }^{7}$ Whilst his archive was compiled during the period of the pogroms, by the time Tcherikower came to write his history, the pogroms had ended with the Soviet victory. The intention of his history, therefore, shifted to become a memorial to the Russian Jewish experience of the Civil War period. ${ }^{8}$

It might be argued that Tcherikower's photographic archive has also become a memorial. It is marked by a scrupulous attention to the naming of the victims it records, wherever this is possible. In doing so, the archive both obeys the rigorous requirements of historiography and of the Talmudic injunction to bear witness to injustice. Unconsciously, perhaps, it mimics the ancient Jewish tradition of the necrology, in which the names and deeds of Jewish martyrs are recorded and regularly read out.

The photograph and the archive both offer the promise of rescue from oblivion, an immortality of sorts. However, Tcherikower's archive does not quite operate like that for Struk and his men. Unlike the named victims, they remain undifferentiated as 'Struk's gang', as though the relentlessness of Tcherikower's historiographic processes has finally entrapped them, forcing them to lie nameless in the uneasy slumber of the archive, side by side with their victims. If the archive does not allow them to be forgotten, namelessness and the passage of time have evacuated their photographs of their original meanings, giving their posturing an uncanny quality akin to a kind of haunting. 
Now imagine this. In a long-forgotten photographer's studio in Chernobyl, Ataman Struk and his men are having their photographs taken. At the shoulder of the photographer, a host of viewers stand, amongst them, of course, ourselves. Our vantage point is the same, but we all see something different. We are able to look at the men through the filter of the entire span of the twentieth century. Some might see the famines, the Holocaust, the Stalinist terror: the unimaginable future that awaited those of the men in these photographs who survived long enough. Others might see in these men our own times as well: the boy soldiers of Somalia and Sudan and the warlords of Afghanistan.

Meanwhile, one of Struk's men has noticed an abandoned child's hobby horse in the corner of the studio, and the joker of the group has pulled it out. On a whim he mounts it, waving his pistol to shouts of encouragement from his friends. The photographer ducks under the blanket one final time: 'Look over here, yes, that's good! Now hold still ... and ... great! That should be a good one!'

Watching this scene unfold, I reflect on the nine to fourteen million casualties of the Civil War. ${ }^{9}$ I imagine that the abject mis en scene of the studio might be an analogue for the tragic condition of the disintegrating Ukrainian state in 1919, its population displaced and traumatised, its infrastructure and economy in ruins. I contemplate the tension between the man's pantomime heroics and the actual violence of his lived life, held in play by the gun. I notice the paradoxical contrast between this man wielding his gun and mimicking a child's game, and the boys watching on the sidelines, dressed in army greatcoats and carrying real weapons.

And then I see something I had not noticed before: the hind leg of the little horse is broken. I see that the man's pose is nothing more than the most tentative of balancing acts, only possible for the seconds required for his moment in front of the camera. In this instant of precariousness it is possible to see written the instability of the times he lived in, it is true, but also of the precariousness of the photographic moment, when we place ourselves in front of the camera, trusting to its hungry eye to immortalise us.

\section{Notes}

${ }^{1}$ Committee of the Jewish Delegations, The Pogroms in the Ukraine Under the Ukrainian Governments (1917-1920), J. Bale, Sons and Danielsson, 1927, p. 118.

${ }^{2} \mathrm{H}$ Abramson, A Prayer for the Government: Jews and Ukrainians in Revolutionary Times, 1917-1920, Ukrainian Research Institute and Centre for Jewish Studies, Harvard University Press, Cambridge, Mass., 1999, p. 116.

${ }^{3}$ Committee of the Jewish Delegations, op. cit., p. 268. 
${ }^{4}$ R Barthes, Camera Lucida: Reflections on Photography, trans. R Howard, Hill and Wang, New York, 1981, pp. 80-81.

5 A Marsh, The Dark Room: Photography and the Theatre of Desire, Macmillan Publishers Australia, Melbourne, 2003, p. 13.

6 Personal communication with M Kelly and M Cecil, Australian War Memorial, January 6, 2010.

${ }^{7}$ J Karlip, 'Between Martyrology and Historiography: Elias Tcherikower and the Making of a Pogrom Historian', East European Jewish Affairs, vol. 38, No 3, December 2008, p. 262.

${ }^{8}$ Ibid., p. 266.

${ }^{9}$ C Merridale, Night of Stone: Death and Memory in Russia, Granta Books, London, 2000, p. 129.

\section{Bibliography}

Abramson, H., A Prayer for the Government: Jews and Ukrainians in Revolutionary Times, 1917-1920. Ukrainian Research Institute and Centre for Jewish Studies, Harvard University Press, Cambridge, Mass., 1999.

Barthes, R., Camera Lucida: Reflections on Photography. trans. Richard Howard, Hill and Wang, New York, 1981.

Committee of the Jewish Delegations, The Pogroms in the Ukraine Under the Ukrainian Governments (1917-1920). J. Bale, Sons and Danielsson, 1927.

Karlip, J., 'Between Martyrology and Historiography: Elias Tcherikower and the Making of a Pogrom Historian'. East European Jewish Affairs, vol. 38, No 3, December 2008.

Marsh, A., The Dark Room: Photography and the Theatre of Desire. Macmillan Publishers Australia, Melbourne, 2003.

Merridale, C., Night of Stone: Death and Memory in Russia. Granta Books, London, 2000.

Anne Brennan is an artist and writer. She is the Head of the Art Theory Workshop at the Australian National University School of Art. 